Documentation of Archaeological Materials from the Cherokee Lake Site (41RK132), Rusk County, Texas

Timothy K. Perttula

Heritage Research Center, Stephen F. Austin State University

Follow this and additional works at: https://scholarworks.sfasu.edu/ita

Part of the American Material Culture Commons, Archaeological Anthropology Commons, Environmental Studies Commons, Other American Studies Commons, Other Arts and Humanities Commons, Other History of Art, Architecture, and Archaeology Commons, and the United States History Commons

Tell us how this article helped you.

This Article is brought to you for free and open access by the Center for Regional Heritage Research at SFA ScholarWorks. It has been accepted for inclusion in Index of Texas Archaeology: Open Access Gray Literature from the Lone Star State by an authorized editor of SFA ScholarWorks. For more information, please contact cdsscholarworks@sfasu.edu. 
Documentation of Archaeological Materials from the Cherokee Lake Site (41RK132), Rusk County, Texas

\section{Creative Commons License}

\section{(c) (1) \&}

This work is licensed under a Creative Commons Attribution-NonCommercial 4.0 International License 


\title{
Documentation of Archaeological Materials from the Cherokee Lake Site (41RK132), Rusk County, Texas
}

\author{
Timothy K. Perttula
}

\section{INTRODUCTION}

The Cherokee Lake site was discovered by Buddy Calvin Jones in 1956, after a terrace area along Tiawichi Creek, inundated by the construction of Lake Cherokee in 1947, had been graded for the construction of fish hatcheries there (Jones 1968:48). Jones identified a single burial and a large storage pit in Area A at the southern end of the terrace, where there was a shallow (0-30 cm bs) midden deposit (Jones 1968:Figure 4).

The burial in Area A is an Historic Nadaco Caddo grave that probably dates to the early $18^{\text {th }}$ century based on the recovery of 15 blue glass beads. This strand of beads was placed near the legs of the deceased individual. The Caddo person had been placed in an extended supine position in a pit that was $1.83 \mathrm{~m}$ long and $0.76 \mathrm{~cm}$ in width, with the head facing towards the west. The estimated depth of the grave was $0.76 \mathrm{~m}$ (Jones 1968:52), and its fill was a dark charcoal-stained midden.

In addition to the strand of glass beads, three ceramic vessels had been placed as funerary offerings in the grave along with a Fresno arrow point by the upper left leg (see Jones 1968:Plate 8b). One Simms Engraved vessel was on the left side of the body, near the foot of the grave, while a second Simms Engraved vessel had been placed by the individual's right foot, along with a Maydelle Incised jar. A plain clay elbow pipe had been placed inside the jar. Two of the vessels from this burial have been recently documented in the collections of the Gregg County Historical Museum in Longview, Texas; the Maydelle Incised vessel is no longer in the collection.

\section{VESSELS FROM HISTORIC CADDO BURIAL}

VESSEL NO.: 2003.08.1058; right side of the body, by the feet

NON-PLASTICS AND PASTE: grog, bone, and hematite

VESSEL FORM: Carinated bowl with a short rim

RIM AND LIP FORM: Inverted rim and a rounded, exterior folded lip

CORE COLOR: C (incompletely oxidized during firing)

INTERIOR SURFACE COLOR: reddish-brown

EXTERIOR SURFACE COLOR: reddish-brown

WALL THICKNESS (RIM, BODY, AND BASE IN MM): rim, $6.0 \mathrm{~mm}$; body, $5.7 \mathrm{~mm}$

INTERIOR SURFACE TREATMENT: smoothed 


\section{EXTERIOR SURFACE TREATMENT: smoothed}

HEIGHT (IN CM): $15.6+$

ORIFICE DIAMETER (IN CM): 21.0

DIAMETER AT BOTTOM OF RIM OR NECK (IN CM): 21.6

BASE DIAMETER (IN CM) AND SHAPE OF BASE: N/A

ESTIMATED VOLUME (IN LITERS): $2.9+$

DECORATION (INCLUDING MOTIF AND ELEMENTS WHEN APPARENT): The short rim panel has four widely-spaced sets of vertical engraved lines (Figure 1). Three sets have seven vertical engraved lines, and the other set has eight closely-spaced vertical engraved lines.

\section{PIGMENT USE AND LOCATION ON VESSEL: none}

TYPE AND VARIETY [IF KNOWN]: Simms Engraved

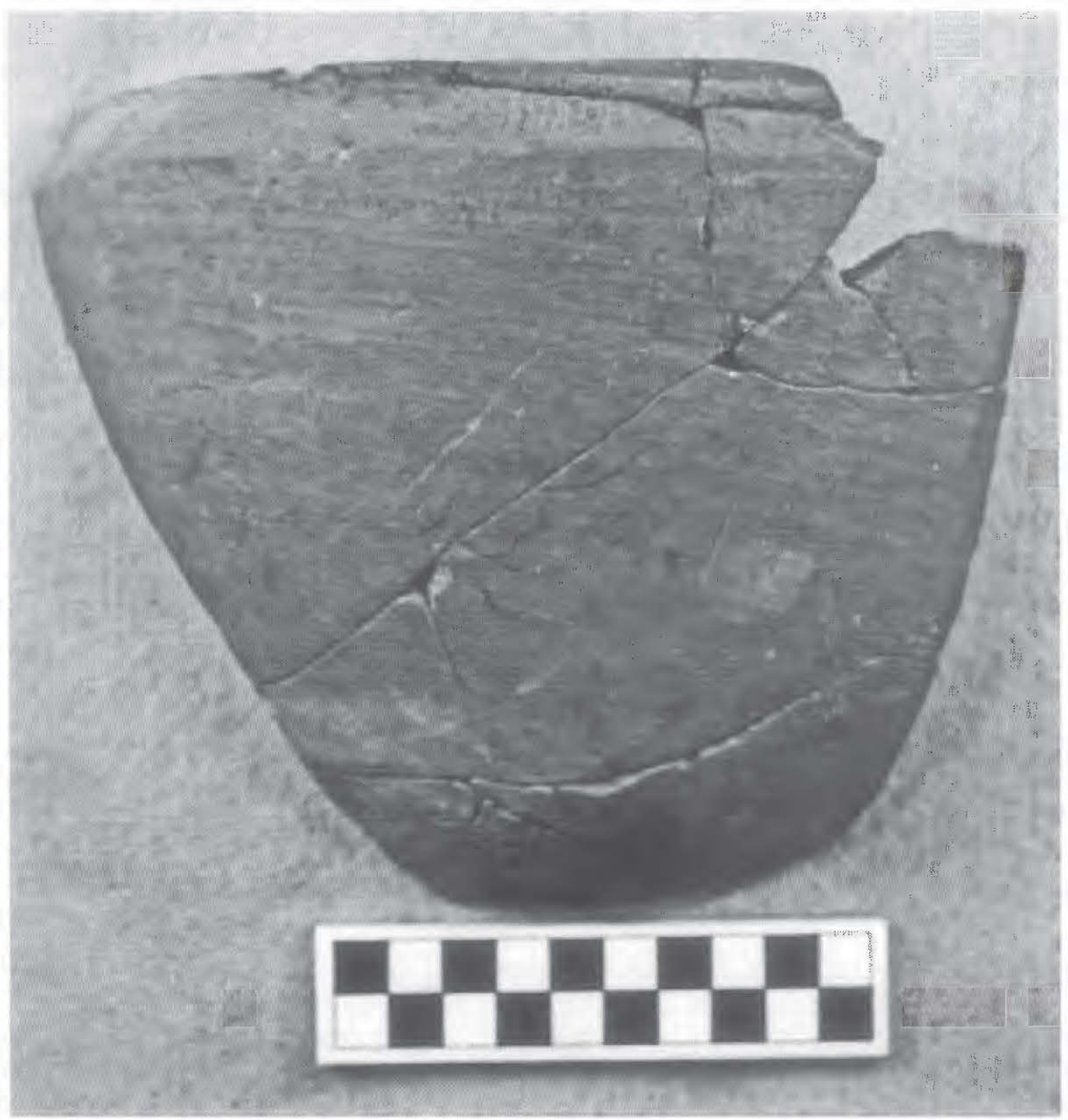

Figure 1. Simms Engraved carinated bowl from near the right foot area of the Cherokee Lake site Historic Caddo burial. 
VESSEL NO.: 2003.08.1139; near the left foot

NON-PLASTICS AND PASTE: grog

VESSEL FORM: Carinated bowl with a short rim

RIM AND LIP FORM: Inverted rim and a rounded, exterior folded lip

CORE COLOR: F (fired in a reducing environment and cooled in the open air)

INTERIOR SURFACE COLOR: yellowish-brown

EXTERIOR SURFACE COLOR: yellowish-brown; fire clouds on the rim and body; organic residue on the rim and body

WALL THICKNESS (RIM, BODY, AND BASE IN MM): rim, $7.5 \mathrm{~mm}$; body, $7.4 \mathrm{~mm}$; base, $10.3 \mathrm{~mm}$

INTERIOR SURFACE TREATMENT: smoothed

EXTERIOR SURFACE TREATMENT: burnished

HEIGHT (IN CM): 21.3

ORIFICE DIAMETER (IN CM): 22.0

DIAMETER AT BOTTOM OF RIM

OR NECK (IN CM): 22.8

BASE DIAMETER (IN CM) AND

SHAPE OF BASE: N/A

ESTIMATED VOLUME (IN

LITERS): 4.2

DECORATION (INCLUDING MOTIF AND ELEMENTS WHEN APPARENT): The rim has horizontal panels filled with upper and lower excised pendant triangles (Figure 2). The ends of each panel are excised brackets. Dividing the panels from one another are large cross-hatched engraved brackets.

PIGMENT USE AND LOCATION ON VESSEL: none

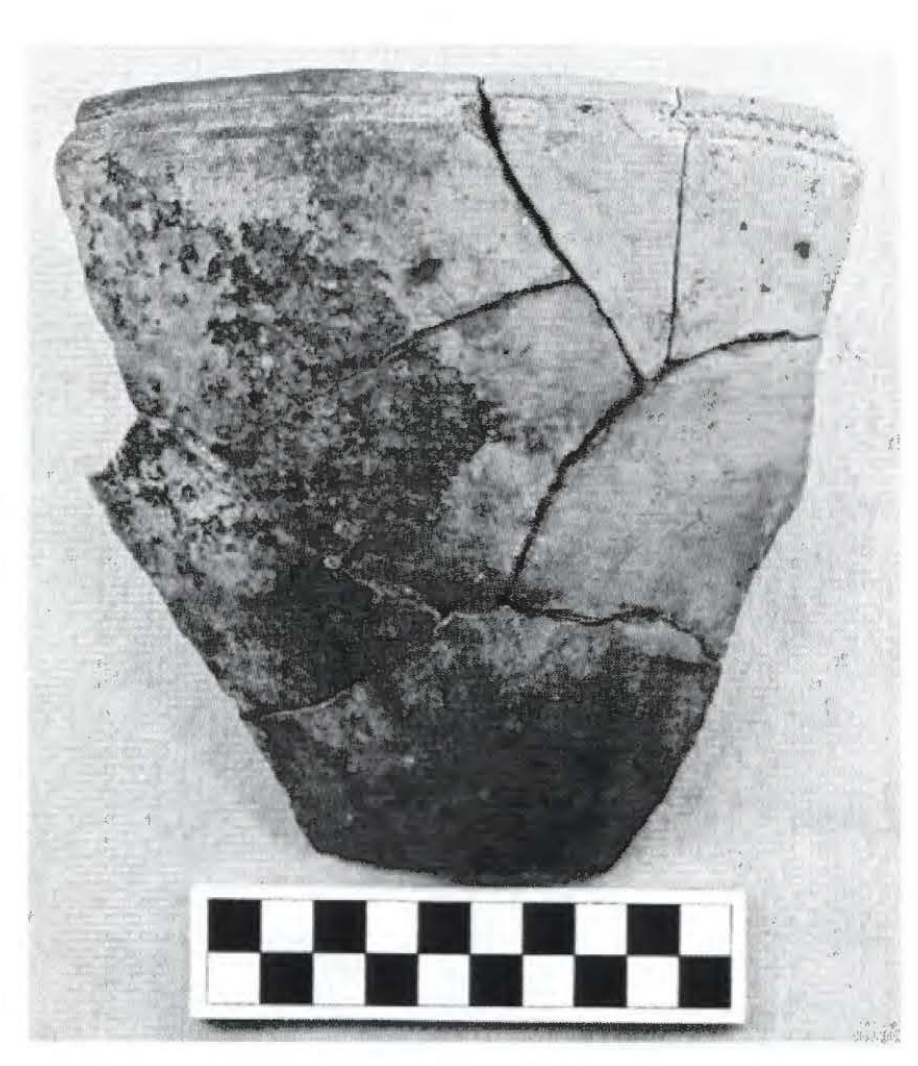

Figure 2. Simms Engraved carinated bowl near the left foot of the

Historic Caddo burial at the Cherokee Lake site.
TYPE AND VARIETY [IF

KNOWN]: Simms Engraved 


\section{Pipe from Historic Caddo Burial}

The ceramic pipe from the Cherokee Lake Historic Caddo burial had been placed inside the Bullard Brushed jar at the time of the burial's interment. The plain bone-tempered clbow pipe has a flaring bowl and a short bi-lobed stem end (Figure 3a-b).

The pipe is $45.0 \mathrm{~mm}$ in height, with a $39.0 \mathrm{~mm}$ long stem (including the lobes). The short bowl is only $19.0 \mathrm{~mm}$ in height, with $5.7 \mathrm{~mm}$ thick walls. The orifice diameter of the bowl is wide $(37.7 \mathrm{~mm})$ relative to its height. The stem is thick $(10.0 \mathrm{~mm})$, with inner and outer orifice diameters of $14.0 \mathrm{~mm}$ and $29.0 \mathrm{~mm}$, respectively.

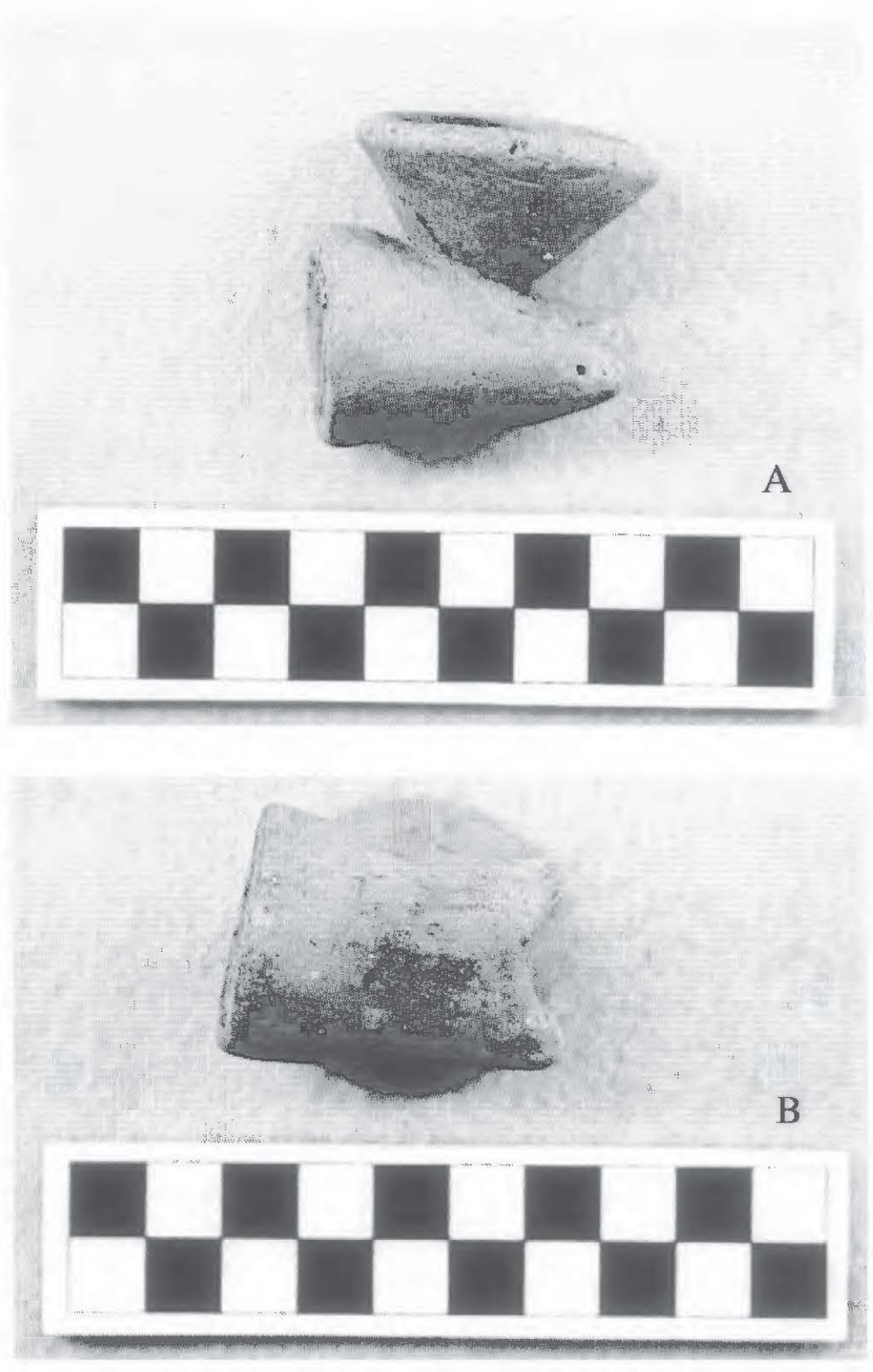

Figures $3 \mathrm{a}$ and $3 \mathrm{~b}$. Ceramic elbow pipe from the Historic Caddo burial at the Cherokee Lake site: a, side view; b, looking down on the stem, showing its bi-lobed end. 


\section{Vessel Sections from the Storage Pit}

The storage pit excavated by Jones at the Cherokee Lake site is primarily associated with a pre-A.D. 1200 Caddo occupation, based on the recovery of Hickory Engraved and Dunkin Incised pottery sherds and Catahoula, Alba, and Bonham arrow points; this occupation probably created the midden deposits found in Area $\mathrm{A}$. The pit itself was $1.2 \times 1.6 \mathrm{~m}$ in dimensions and extended to ca. $1.1 \mathrm{~m}$ below surface, extending into the red clay B-horizon (Jones 1968:56). At the top of the graded pit feature was a small Bullard Brushed jar and a large fragment of another Bullard Brushed jar, while portions of a large bowl were found on the pit floor.

VESSEL NO.: 2003.08.1959; jar section lound at the top of the storage pit

NON-PLASTICS AND PASTE: grog

VESSEI, FORM: Jar

RIM AND IIIP FORM: Everted rim and rounded lip

CORE COLOR: B (fired and cooled in a reducing environment)

INTERIOR SURFACE COLOR: dark grayish-brown

EXTERIOR SURFACE COLOR: very dark grayish-brown

WALL THICKNESS (RIM, BODY, AND BASE IN MM): rim, $8.6 \mathrm{~mm}$; body, $9.2 \mathrm{~mm}$

INTERIOR SURFACE TREATMENT: smoothed

EXTERIOR SURFACE TREATMENT: none

IIEIGHT (IN CM): 24.0+

ORIFICE DIAMETER (IN CM): 22.0

DLAMETER AT BOTTOM OF RIM OR NECK (IN CM): 21.0

BASE DIAMETER (IN CM) AND SHAPE OF BASE: N/A

ESTIMATED VOLUME (IN LITERS): $6.9+$

DECORATION (INCLUDING MOTIF AND ELEMENTS WHEN APPARENT): The rim has horizontal brushing marks. The vessel body has a combination of horizontal, diagonal, vertical, and overlapping brushing marks that cover the entire body surface (Figure 4).

PIGMENT USE AND LOCATION ON VESSEL: none

TYPE AND VARIETY [IF KNOWN]: Bullard Brushed 


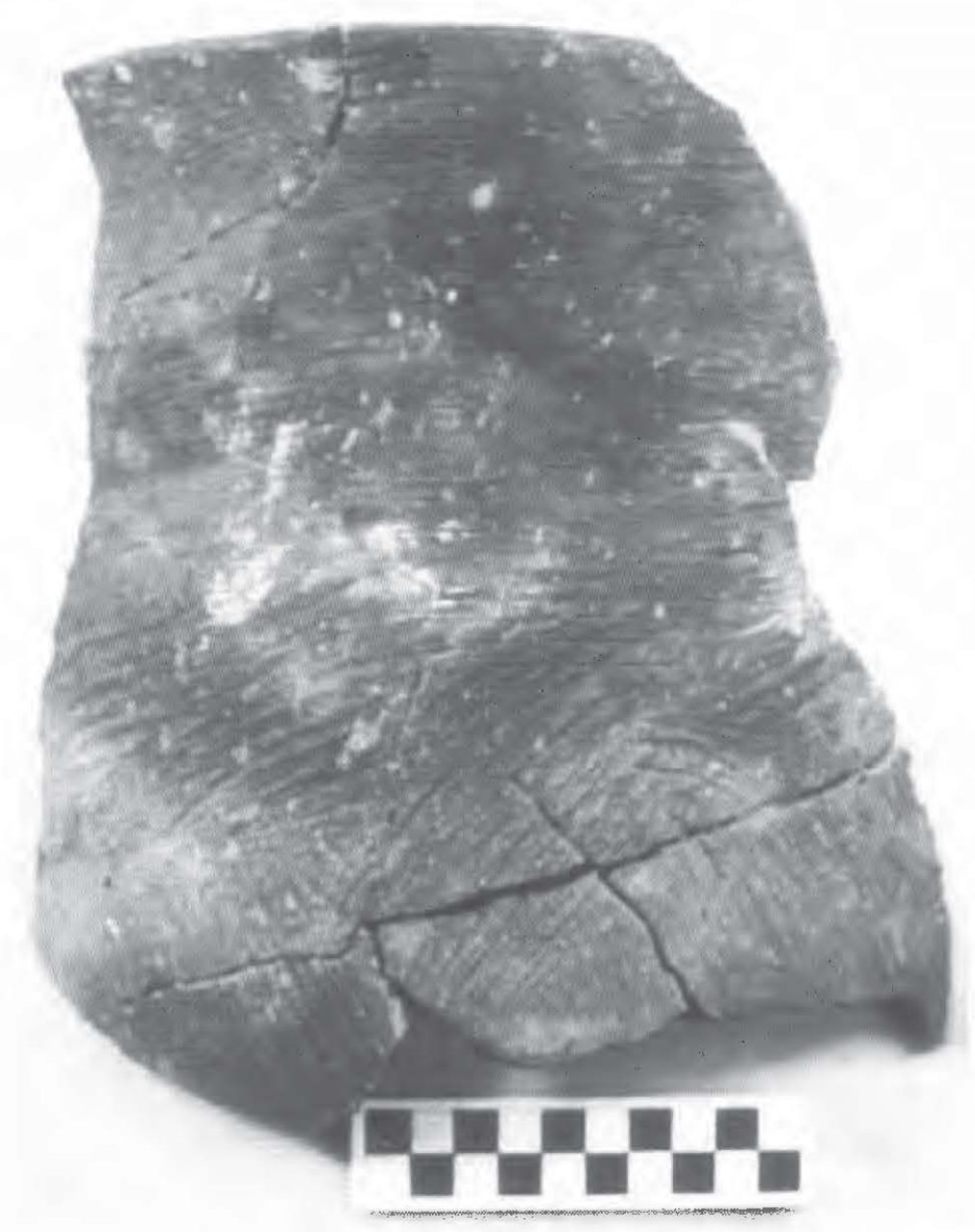

Figure 4. Bullard Brushed jar placed near the top of the storage pit at the Cherokee Lake site.

VESSEL NO.: 2003.08.1958, found on pit floor

NON-PLASTICS AND PASTE: grog

VESSEL FORM: Bowl with two suspeusion holes just below the rim, and a third suspension hole on the vessel body (Figure 5)

RIM AND LIP FORM: Direct rim and rounded lip

CORE COLOR: $\mathrm{B}$ (fired and cooled in a reducing environment)

INTERIOR SURFACE COLOR: very dark grayish-brown

EXTERIOR SURFACE COLOR: dark grayish-brown

WALL THICKNESS (RIM, BODY, AND BASE IN MM): rim, $5.9 \mathrm{~mm}$ : body, $6.2 \mathrm{~mm}$; base, $11.2 \mathrm{~mm}$ INTERIOR SURFACE TREATMENT: smoothed 


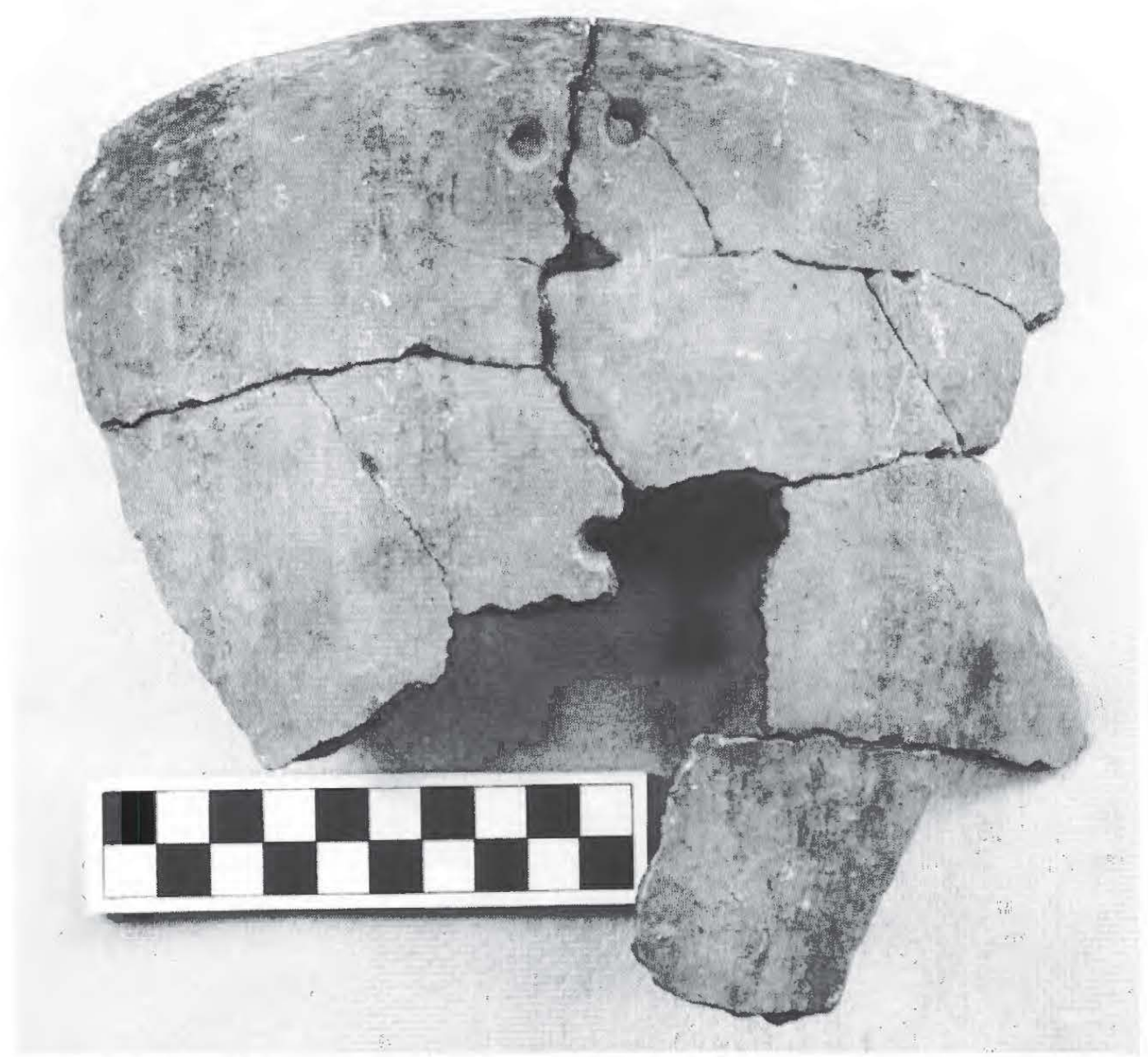

Figure 5. Plain bowl from the floor of a storage pit at the Cherokee Lake site.

EXTERIOR SURFACE TREATMENT: smoothed

HEIGHT (IN CM): 18.0 (from Jones 1968:57)

ORIFICE DIAMETER (IN CM): 26.0

DIAMETER AT BOTTOM OF RIM OR NECK (IN CM): N/A

BASE DIAMETER (IN CM) AND SHAPE OF BASE: N/A

ESTIMATED VOLUME (IN LITERS): 3.7

DECORATION (INCLUDING MOTIF AND ELEMENTS WHEN APPARENT): Plain PIGMENT USE AND LOCATION ON VESSEL: none

TYPE AND VARIETY [IF KNOWN]: Unidentified plain ware 


\section{SUMMARY AND CONCLUSIONS}

The Gregg County Historical Museum collections from the Cherokee Lake site (4IRK132) include two large Simms Engraved carinated bowls and a distinctive plain and bi-lobed elbow pipe from an Historic Nadaco Caddo burial. Glass beads reported by Jones (1968) to have been recovered from this burial indicates it dates to the early part of the $18^{\text {th }}$ century A.D. The remainder of the collection consists of two vessel sections Jones excavated from a large storage pit filled with trash. The vessel section from the top of the pit was part of a large Bullard Brushed jar; this jar is likely associated with the Historic Nadaco Caddo occupation. The remaining vessel section is a large plain bowl with suspension holes from the pit floor. This vessel section occurs in association with pre-A.D. 1200 Caddo ceramic sherds, long-stemmed clay pipe sherds, and stemmed arrow point styles.

\section{REFERENCES CITED}

Jones, B. C.

1968 The Kinsloe Focus: A Study of Seven Historic Caddoan Sites in Northeast Texas. Master's thesis, Department of Anthropology, University of Oklahoma, Norman. 